\title{
Severity of bronchiolitis in infants is associated with their parents' tobacco habit
}

\author{
Diego Rodriguez-Alvarez ${ }^{1}$, Cristina Rodriguez-de Tembleque ${ }^{1}$, Elena Perez-Costa ${ }^{1}$, Emilio \\ Cendejas-Bueno $^{1}$, and Pedro de la Oliva ${ }^{1}$ \\ ${ }^{1}$ La Paz University Hospital
}

September 11, 2020

\begin{abstract}
Objectives: Risk factors for severe acute bronchiolitis in previously healthy infants are scarcely known. This study investigated the effect of tobacco smoke exposure among severely Pediatric Intensive Care Unit (PICU) patients. Design: A prospective epidemiological observational study Setting: Tertiary pediatric medical center. Pediatric Intensive Care Unit (PICU) of Children's University Hospital La Paz Patient selection: Infants with bronchiolitis younger than 2 years of age during the October 2017 to March 2018 outbreak Methodology: On admission, parents were asked whether they smoked. In children who required invasive mechanical ventilation, endotracheal aspirate was collected at the time of intubation. Results: A total of 102 patients with bronchiolitis were studied. Among these, 14 (47\%) of 30 infants whose parents smoked required invasive mechanical ventilation vs. $14(19 \%)$ of 72 whose parents were nonsmokers ( $\mathrm{p}=0.007)$ (RR 2.4; 95\% CI 1.3-4.4). Among patients on invasive mechanical ventilation, $10(71 \%)$ of 14 infants with secondhand smoke exposure presented PBI vs. $3(21 \%)$ of 14 in the unexposed ( $\mathrm{p}=0.012)$ (RR 3.3; 95\% CI 1.2-9.6). PICU stay was 3 (IQR 3-6) days in infants whose parents didn't smoke, and 5 (IQR 3-11) days in infants whose parents smoked $(\mathrm{p}=0.01)$. Conclusions: Secondhand smoke exposure is an additional high risk for pulmonary bacterial superinfection, invasive mechanical ventilation and PICU length of stay in infants with severe acute bronchiolitis
\end{abstract}

\section{INTRODUCTION}

Bronchiolitis is a disorder commonly caused by viral lower respiratory tract infection in infants. Signs and symptoms typically begin with rhinitis and cough, which can progress to tachypnea, wheezing, rales, use of accessory muscles, and/or nasal flaring ${ }^{1}$. Respiratory syncytial virus (RSV) acute bronchiolitis (AB) is the most common cause of infant hospitalization ${ }^{2,3}$.

The global RSV-acute lower respiratory infection (ALRI) hospitalization estimate, reported per 1000 children per year (95\% confidence interval [CI]), was 19.19 (15.04-24.48) among children $<1$ year of age ${ }^{4}$. Globally in 2015, an estimated 33.1 million (uncertainty range [UR] 21.6-50.3) episodes of RSV-ALRI resulted in approximately 3.2 million (2.7-3.8) hospital admissions and 59,600 (48,000-74,500) in-hospital deaths in children younger than 5 years. In children younger than 6 months, 1.4 million (UR 1.2-1.7) hospital admissions, and 27,300 (UR 20,700-36,200) in-hospital deaths were due to RSV-ALRI ${ }^{5}$. Endotracheal intubation (ETI) is required in approximately $24 \%$ of patients admitted to the pediatric intensive care unit (PICU) ${ }^{6}$.

There are many risk factors for RSV infection and bronchiolitis: age younger than 6 months ${ }^{7}$, older siblings ${ }^{8,9}$, lung disease ${ }^{10,11}$, congenital heart disease ${ }^{12}$, born before 35 weeks' gestation ${ }^{13}$, and exposure to second-hand smoke $^{14,15}$. However, risk factors for severe acute bronchiolitis (SAB) in previously healthy infants are not well known.

The main objective of this study was to investigate the effect of tobacco smoke exposure among severely PICU patients. 


\section{MATERIALS AND METHODS}

\section{Study design}

This was an observational, prospective, nonrandomized cohort study on infants younger than 2 years presenting a first acute episode of $\mathrm{AB}$ who were admitted to La Paz University Hospital's PICU between October 2017 and March 2018. Parents' or legal guardians' written consent was requested to participate in the study. The study was approved by the Hospital's Ethics Committee (PI-2931).

\section{Study population}

The diagnosis of $\mathrm{AB}$ was established in children younger than 2 years who had a viral upper respiratory tract prodrome followed by increased respiratory effort and wheezing, during an epidemic outbreak ${ }^{16}$. Clinical respiratory severity was scored using the Wood-Downes system ${ }^{17}$.

Tracheostomy patients, oncology patients, terminal patients, and patients on palliative care were excluded from the study.

\section{Data collection}

At admission, the patients' parents were asked whether they smoked, whether the parents were atopic, and whether the patient had siblings or went to nursery school.

A thoracic X-ray examination and a blood test were performed. Procalcitonin (PCT) was quantified by electrochemiluminescence with the Cobas e-411@ analyzer (Roche). C-reactive protein (CRP) was quantified by the CRP Flex method (Dimension Vista, Siemens).

The following microbiological samples were collected from all patients: RSV antigen, multiple CRP for respiratory viruses (PneumoVir) from a nasal swab, blood culture, and a urine culture.

In patients requiring IMV, an endotracheal aspirate (ETA) sample was collected at intubation. Proven bacterial coinfection was defined as $>100,000$ colony-forming units $/ \mathrm{mL}(\mathrm{CFU} / \mathrm{mL})$, and bronchial tree colonization as [?]100,000 $\mathrm{CFU} / \mathrm{mL}$.

At discharge, data on the number of days of therapy required, and the need for nasal cannulas, high-flow oxygen therapy (HFOT), noninvasive mechanical ventilation (NIMV), and IMV were collected.

In patients with suspected sepsis or PCT [?]0.5 ng/mL and in patients requiring IMV, antibiotic therapy was initiated according to the PICU's AB protocol.

Bronchiolitis severity was established by the need for and duration of IMV as well as by PICU length of stay.

\section{Statistical analysis}

Data were recorded in Excel v15.0 and analyzed using IBM SPSS Statistical package, v. 24. Normal goodness of fit was evaluated using the Kolmogorov-Smirnov test. The nonparametric data are expressed as median (Mdn) and interquartile range (IQR 25\%-75\%). For the nonparametric contrast of 2 unrelated samples, the Mann-Whitney U test was used. Relative risk computed as $\mathrm{I}_{\text {exposed }} / \mathrm{I}_{\text {unexposed }}\left(\mathrm{I}_{\mathrm{e}} / \mathrm{I}_{\mathrm{u}}\right)$ was used as an association measure. Rosenthal's $\mathrm{r}$ calculated from Wilcoxon $\mathrm{Z}$ values $(\mathrm{r}=\mathrm{Z} / \mathrm{N}$ root), attributable risk (AR) as the difference between the incidence of disease in the exposed population versus incidence in the unexposed population, calculated as Ie-Iu, attributable fraction among the exposed (AFe) as the proportion of incidents in the exposed group that are attributable to the risk factor calculated as (Ie-Iu)/Ie and population-attributable fraction (PAF) the percentage of cases in the entire study population that can be attributed to the exposure calculated as $(\mathrm{PAF})=$ (proportion of cases exposed $\mathrm{x}$ AFe) were used for impact measurement or effect size. To analyze the association among qualitative variables, the chi-squared test was used. Statistical significance was set at $\mathrm{p}<0.05$.

\section{RESULTS}

\section{Study sample}


Between October 2017 and March 2018, a total of 396 children with AB were admitted to the La Paz University Children's Hospital (Madrid, Spain). Of these 396 children, 102 with SAB were admitted to the PICU. These 102 patients ( $52 \%$ males, $48 \%$ females) with Mdn = 1 (IQR 0-4) month old were studied. Of 102 patients, $27 \%$ required IMV, 38\% NIMV, and 93\% HFOT either as an isolated therapy or following therapy de-escalation from IMV. IMV duration was 6.5 (IQR 3.3-9.0) days. PICU stay was 3.0 (IQR 2.0-4.0) days in nonintubated patients and 9.5 (IQR 6.2-11.0) days in IMV patients $\mathrm{p}<0.001$.

\section{Parental smoking}

Table 1 shows the features and vital signs of the patients whose parents smoked and the patients whose parents did not smoke. Infants with parents who smoked had a higher radiological involvement in thoracic X-ray examination (70\% vs. $50 \%$ ) compared with those who had not been exposed to tobacco smoke (Figure 2A ).

Parental smoking was associated both with PICU length of stay (Figure 1A ) and with the need for IMV (Figure 2A ). For infants on IMV, the parental smoking AR was $28 \%$ (95\% CI 9\%-48\%), and the AFe was $57 \%$ (95\% CI 37\%-77\%). Of 28 IMV-SAB infants, 8 IMV cases (PAF 29\%) can be attributed to passive environmental tobacco smoke (ETS) exposure.

Among those infants who required IMV, the fact that their parents smoked was associated with more days of IMV (Figure 1B ) and with a higher rate of pulmonary bacterial infection (PBI) in the ETA (Figure 2B ). As far as PBI is concerned, the parental smoking AR was 50\% (95\% CI 13\%-87\%), and the AFe was $70 \%$ (95\% CI 44\%-96\%). Of 13 infants with PBI on IMV, 7 (PAF 54\%) cases can be attributed to ETS exposure.

\section{Microbiology}

One virus was isolated in $71.6 \%$ of the patients, and 2 viruses in $14.7 \%$ of the patients, with RSV present in $78.4 \%$ of cases. No more than 2 viruses were isolated in any patient. In $12.7 \%$ of cases, no virus was isolated. Among the patients requiring IMV, 1 virus was isolated in $71.4 \%$ of patients, and 2 viruses in $21.4 \%$ of patients. No virus was isolated in $7.1 \%$ of patients. Table 2 shows the virus isolation results from nasal swabs. Infants with parents who smoked had a higher RSV infection rate ( $87 \%$ vs. $76 \%$ ) compared with those who had not been exposed to tobacco smoke (Figure 2A) .

ETA was performed just after intubation in all the 28 patients requiring IMV. A total of 13/28 (46.4\%) intubated patients presented with bacterial isolation in the infection range; in $7 / 28$ (25\%), 2 or more bacteria were isolated. In $7 / 28(25 \%)$ intubated patients, microorganisms in the colonization range were isolated. In $8 / 28(28.6 \%)$, no other microorganisms were isolated. Of the 8 infants on IMV in whom no microorganisms were isolated, $5(62.5 \%)$ had received previous antibiotic therapy. Table 3 shows the percentage of ETAisolated microorganisms in patients whose parents smoked and in those whose parents did not smoke.

Blood cultures were positive in $7(6.9 \%)$, and urine cultures in $6(5.9 \%)$ of the patients.

\section{DISCUSSION}

The main finding of our study was that in infants with SAB, parental smoking is associated with a need for IMV and with a risk of BPI in those patients who required IMV.

\section{Parental smoking}

This is the first study to show that severity in SAB infants is associated with the fact that their parents smoked. The differences found in the rate of IMV and PBI between these 2 groups were clinically relevant. Infants with $\mathrm{SAB}$ whose parents smoked needed to be intubated in 27 additional cases per 100 patients compared with those whose parents did not smoke. This result means that $58 \%$ of the intubations in the group of infants whose parents smoked were due solely to the fact that their parents smoked.

In addition, IMV duration and PICU length of stay were also significantly higher in smoke-exposed patients. 
The higher risk for ETI and need for IMV can be most likely explained by the fact that patients exposed to tobacco smoke have a higher bacterial superinfection rate, as we can see in ETA cultures of intubated patients ( $71 \%$ positive if parents smoked vs. $21 \%$ positive if the parents did not smoke).

Both groups have similar characteristics. The only significant difference between these two groups was gestational age. Although there were slight differences in gestational age, the median of both groups corresponded to term infants.

Cigarette smoking has been shown to be a substantial risk factor for important bacterial and viral airway infections. The mechanisms by which smoking increases the risk of infections include structural changes in the respiratory tract and a reduction in the immune response ${ }^{18}$.

ETS exposure is known to be an important risk factor for childhood lower respiratory tract infections ${ }^{19}$. Passive ETS exposure has been associated with lower oxygen saturation and higher clinical severity scores ${ }^{20}$, and it significantly increases the risk of hospitalization for bronchiolitis in the first year of life ${ }^{21}$. Furthermore, maternal cigarette smoking during pregnancy puts children hospitalized with bronchiolitis at significantly higher risk of intensive care use, and postnatal ETS might exacerbate this risk ${ }^{22}$.

The findings in our study imply that in infants with SAB, the risk of a severe event, such as intubation, is increased by ETS exposure. All these infants survived because they received appropriate treatment in a PICU. Bronchiolitis is a significant cause of respiratory disease worldwide, and appropriate access to a PICU is not guaranteed for all infants.

This study has some limitations. The sample we analyzed consisted of only 102 patients. However, it represents the complex PICU population with SAB, a situation that physicians face on a daily basis, and this sample has similar characteristics to others reported ${ }^{23,24}$.

Memory-based parental reports of short-term ETS exposure can play an important role in quantifying ETS exposure in infants and children ${ }^{25}$. The degree of exposure to tobacco smoke is not known, nor is the duration of time the patients were exposed. Further studies are needed to measure the ETS exposure of the children who have $\mathrm{AB}$, and to know if this risk factor could be removed, consequently reducing the severity of bronchiolitis in these patients, and the number of patients requiring IMV or PICU stay.

\section{Viral infection}

This is the first study characterizing the various types of viruses that PICU-admitted patients with acute bronchiolitis can present. For this purpose, we used multiple CRP for respiratory viruses (PneumoVir). RSV remains the most commonly isolated virus in these patients, followed by bocavirus and rhinovirus at much lower percentages. Viral isolation was similar to that of patients from other studies ${ }^{26}$, with a higher amount of bocavirus. No differences were found in the proportions of isolated viruses among patients according to their parents' smoking habits. Therefore, viral infection does not appear to explain the greater severity in ETS exposure infants with acute bronchiolitis.

\section{Pulmonary bacterial infection}

ETI was performed orally. This process might have moved bacteria from the upper airway to the lower tract, which could account for the bacterial colonization of the lower airways. This bacterial pathogen colonization from the respiratory airways - which was present in $25 \%$ of intubated patients - suggests a high prevalence of upper airway bacterial coinfection/colonization in $\mathrm{AB}$ patients, which is a risk factor for pneumonia.

Our study shows that $46 \%$ of patients on IMV presented with bacterial or multibacterial isolation in BAS in the infection range. This proportion is likely to be higher, since $66.7 \%$ of children with negative culture had received previous antibiotic therapy, which could have inhibitedin vitro bacterial growth.

These results are in line with previous studies that reported PBI occurred in 37\%-44\% of children with bronchiolitis admitted to PICUs ${ }^{27-29}$ and are consistent with the findings of other authors who found that bacterial isolation in the bloodstream, CSF, or urine in infants with RSV bronchiolitis is uncommon, and 
that Moraxella catarrhalis and Haemophilus influenzae were the most frequent BAS-isolated microorganisms in patients requiring $\mathrm{IMV}^{30}$.

Our hospital is a tertiary level hospital that cares for children with complex and chronic pathologies. This fact explains the isolation of some typical nosocomial bacteria in ETA.

\section{CONCLUSIONS}

ETS exposure is an additional high-risk factor for PBI, the need for IMV, longer IMV duration, and longer PICU length of stay in infants with SAB. Given the high incidence of SAB among infants around the world and the high prevalence of parental smoking, public health education and measures aimed to fully eliminate ETS exposure among infants especially during AB breakouts are urgently needed.

\section{References}

1. Agency for Healthcare Research and Quality. Management of Bronchiolitis in Infants and Children. Evidence Report/ Technology Assessment No. 69. Rockville, MD: Agency for Healthcare Research and Quality; 2003. AHRQ Publication No. 03- E014

2. Pierangeli A, Scagnolari C, Antonelli G: Respiratory syncytial virus. Minerva Pediatr. 2018 Dec;70(6):553565.

3 Fitzgerald DA, Kilham HA. Bronchiolitis: assessment and evidence-based management. Med J Aust 2004; 180:399.

4 Stein RT, Bont LJ, Zar H, et al. Respiratory syncytial virus hospitalization and mortality: Systematic review and meta-analysis. Pediatr Pulmonol 2017; 52:556.

5 Shi T, McAllister DA, O'Brien KL, et al. Global, regional, and national disease burden estimates of acute lower respiratory infections due to respiratory syncytial virus in young children in 2015: a systematic review and modelling study. Lancet 2017; 390:946.

6 Flores-Gonzalez JC, Mayordomo-Colunga J, Jordan I et al (2017) Prospective multicenter study on the epidemiology and current therapeutic management of severe bronchiolitis in Spain. Biomed Res Int 2017:2565397

7 Boyce TG, Mellen BG, Mitchel EF Jr, et al. Rates of hospitalization for respiratory syncytial virus infection among children in medicaid. J Pediatr 2000; 137:865.

8 Munywoki PK, Koech DC, Agoti CN, et al. Frequent Asymptomatic Respiratory Syncytial Virus Infections During an Epidemic in a Rural Kenyan Household Cohort. J Infect Dis 2015; 212:1711.

9 Sheridan-Pereira M, Murphy J, Sloan J, et al. Respiratory Syncytial Virus Preterm (32-36 Completed Weeks of Gestation) Risk Estimation Measure for RSV Hospitalization in Ireland: A Prospective Study. Pediatr Infect Dis J 2016; 35:19.

10 Welliver RC Sr, Checchia PA, Bauman JH, et al. Fatality rates in published reports of RSV hospitalizations among high-risk and otherwise healthy children. Curr Med Res Opin 2010; 26:2175.

11 Mitchell I, Wong SK, Paes B, et al. Respiratory syncytial virus prophylaxis in cystic fibrosis: the Canadian registry of palivizumab data (2005-2016). Eur J Clin Microbiol Infect Dis 2018; 37:1345.

12 Kristensen K, Stensballe LG, Bjerre J, et al. Risk factors for respiratory syncytial virus hospitalisation in children with heart disease. Arch Dis Child 2009; 94:785.

13 Gijtenbeek RG, Kerstjens JM, Reijneveld SA, et al. RSV infection among children born moderately preterm in a community-based cohort. Eur J Pediatr 2015; 174:435.

14 von Linstow ML, Hogh M, Nordbo SA, et al. A community study of clinical traits and risk factors for human metapneumovirus and respiratory syncytial virus infection during the first year of life. Eur J Pediatr 
2008; $167: 1125$.

15 Maedel C, Kainz K, Frischer T, et al. Increased severity of respiratory syncytial virus airway infection due to passive smoke exposure. Pediatr Pulmonol 2018; 53:1299.

16. Ralston SL, Lieberthal AS, Meissner HC, Alverson BK, Baley JE, Gadomski AM, et al. Clinical practice guideline: the diagnosis, management, and prevention of bronchiolitis. Pediatrics 2014;134:e1474-e1502

17 Wood DW, Downes JJ, Lecks HI. A clinical scoring system for the diagnosis of respiratory failure. Preliminary report on childhood status asthmaticus. Am J Dis Child 1972;123:227-228

18 Arcavi L, Benowitz NL: Cigarette smoking and infection. Arch Intern Med. 2004;164(20):2206.

19 Zar HJ, Ferkol TW. The global burden of respiratory disease - impact on child health. Pediatr Pulmonol. 2014;49:430-434

20 Behrooz L, Balekian DS, Faridi MK, et al: Prenatal and postnatal tobacco smoke exposure and risk of severe bronchiolitis during infancy. Respir Med. 2018 Jul;140:21-26.

21 Lanari M, Vandini S, Adorni F, et al. Prenatal tobacco smoke exposure increases hospitalizations for bronchiolitis in infants. Respir Res. 2015;16:1-9

22 Stevenson MD, Mansbach JM, Mowad E, et al. Prenatal versus postnatal tobacco smoke exposure and intensive care use in children hospitalized with bronchiolitis. Acad Pediatr. 2016;16:446-452. Epub $2015 / 11 / 12$.

23 Ghazaly M, Nadel S. Characteristics of children admitted to intensive care with acute bronchiolitis. Eur J Pediatr. 2018 Jun;177(6):913-920

24 Pham H, Thompson J, Wurzel D, Duke T. Ten years of severe respiratory syncytial virus infections in a tertiary paediatric intensive care unit. J Paediatr Child Health. 2020 Jan;56(1):61-67

25 Matt GE, Wahlgren DR, Hovell MF, et al. Measuring environmental tobacco smoke exposure in infants and young children through urine cotinine and memory-based parental reports: empirical findings and discussion. Tob Control. 1999;8(3):282-289. doi:10.1136/tc.8.3.282

26 Miller EK, Gebretsadik T, Carroll KN, et al: Viral etiologies of infant bronchiolitis, croup and upper respiratory illness during 4 consecutive years. Pediatr Infect Dis J. 2013;32(9):950-955

27 Wiegers HM, Nijen L, Van Woensel JBM, et al. Bacterial co-infection of the respiratory tract in ventilated children with bronchiolitis; a retrospective cohort study. BMC Infect Dis. 2019;19:938.

28 Thorburn K, Harigopal S, Reddy V, et al. High incidence of pulmonary bacterial co-infection in children with severe respiratory syncytial virus (RSV) bronchiolitis. Thorax. 2006;61:611-615. doi: 10.1136/thx.2005.048397

29 Duttweiler L, Nadal D, Frey B. Pulmonary and systemic bacteria co-infections in severe RSV bronchiolitis. Arch Dis Child. 2004;89:1155-1157. doi: 10.1136/adc.2004.049551

30 Randolph AG, Reder L, Englund JA: Risk of bacterial infection in previously healthy respiratory syncytial virus-infected young children admitted to the intensive care unit. Pediatr Infect Dis J. 2004;23: 990-994.

Tables

Table 1. Patient Features.

\begin{tabular}{lll}
\hline & Smoking parents, $\mathrm{n}=30$ & Non-smoking parents, $\mathrm{n}=$ \\
\hline Age, mo, median (IQR) & $2(0-6.3)$ & $1(0-3.0)$ \\
Gender, male, n (\%) & $13(43)$ & $40(56)$ \\
Gestational age, days, median, (IQR) & $260(238-276)$ & $270(258-280)$
\end{tabular}




\begin{tabular}{|c|c|c|}
\hline & Smoking parents, $\mathrm{n}=30$ & Non-smoking parents, $\mathrm{n}=$ \\
\hline Weight at birth, gr, median, (IQR) & $2850(1795-3250)$ & $3070(2531-3428)$ \\
\hline Previous administration of palivizumab, n (\%) & $3(10)$ & $4(6)$ \\
\hline Apneas ${ }^{a}, \mathrm{n}(\%)$ & $11(37)$ & $23(32)$ \\
\hline Pulmonary disease ${ }^{\mathrm{b}}, \mathrm{n}(\%)$ & $1(3)$ & $0(0)$ \\
\hline Heart disease ${ }^{\mathrm{c}}, \mathrm{n}(\%)$ & $5(17)$ & $6(8)$ \\
\hline Nursery school enrollment, n (\%) & $3(10)$ & $5(7)$ \\
\hline Siblings, n (\%) & $7(23)$ & $17(24)$ \\
\hline PICU admission HR, bpm, median, (IQR) & $160(145-175)$ & $165(150-180)$ \\
\hline PICU admission systolic blood pressure, $\mathrm{mmHg}$, median, (IQR) & $103(90-118)$ & $97(85-110)$ \\
\hline PICU admission RR, bpm, median, (IQR) & $45(35-61)$ & $40(34-60)$ \\
\hline PICU admission score Wood-Downes-Ferres ${ }^{\mathrm{d}}$ modified, median, (IQR) & $7(5-9)$ & $7(5-8)$ \\
\hline
\end{tabular}

$\mathrm{HR}=$ heart rate. $\mathrm{IQR}=$ interquartile range. $\mathrm{PICU}=$ Pediatric Intensive Care Unit. $\mathrm{RR}=$ respiratory rate. ${ }^{a}$ Episode of apnea prior to admission. ${ }^{\mathrm{b}}$ Bronchopulmonary dysplasia. ${ }^{\mathrm{c}}$ Persistent arterial duct, patent foramen ovale, interatrial communication. ${ }^{\mathrm{d}}$ Wood D, Downes J, Lecks H. A clinical scoring system for the diagnosis of respiratory failure. Am J Dis Child. 1972;123: 227-8.

Table 2. Virus isolation. Pneumovir $($ ) results.

\begin{tabular}{llll}
\hline Virus & Smoking parents n=30 & $\begin{array}{l}\text { Non-smoking parents } \\
\mathrm{n}=72\end{array}$ & $\mathrm{P}$ \\
\hline RSV a & $26(87 \%)$ & $55(76 \%)$ & 0.242 \\
$\begin{array}{l}\text { Bocavirus } \\
\text { Rhinovirus }\end{array}$ & $2(7 \%)$ & $6(8 \%)$ & 0.775 \\
$\begin{array}{l}\text { Parainfluenza virus } \\
\text { type 3 }\end{array}$ & $1(3 \%)$ & $5(7 \%)$ & 0.480 \\
$\begin{array}{l}\text { Parainfluenza virus } \\
\text { type 4 }\end{array}$ & $0(0 \%)$ & $2(3 \%)$ & 0.120 \\
$\begin{array}{l}\text { Influenza A } \\
\text { Influenza C }\end{array}$ & $1(3 \%)$ & $2(3 \%)$ & 0.357 \\
$\begin{array}{l}\text { Human } \\
\text { metapneumovirus }\end{array}$ & $0(0 \%)$ & $1(1 \%)$ & 0.880 \\
Enterovirus & $1(3 \%)$ & $3(4 \%)$ & 0.843 \\
\hline
\end{tabular}

${ }^{a}$ RSV: respiratory syncytial virus

Table 3. Endotracheal aspirate isolation in patients requiring IMV

\begin{tabular}{|c|c|c|c|c|}
\hline Bacteria n, (\%) & $\begin{array}{l}\text { Smoking parents } \\
\mathrm{n}=14 \text { Infection }^{\mathrm{a}} \\
\mathrm{n}=10 \text { Colonization }^{\mathrm{b}} \\
\mathrm{n}=1\end{array}$ & $\begin{array}{l}\text { Smoking parents } \\
\mathrm{n}=14 \text { Infection }^{\mathrm{a}} \\
\mathrm{n}=10 \text { Colonization }^{\mathrm{b}} \\
\mathrm{n}=1\end{array}$ & $\begin{array}{l}\text { Non-smoking } \\
\text { parents } n=14 \\
\text { Infection } n=3 \\
\text { Colonization } n=6\end{array}$ & $\begin{array}{l}\text { Non-smoking } \\
\text { parents } \mathrm{n}=14 \\
\text { Infection } \mathrm{n}=3 \\
\text { Colonization } \mathrm{n}=6\end{array}$ \\
\hline $\begin{array}{l}\text { Moraxella } \\
\text { catharralis }\end{array}$ & $3(21)$ & & & $1(7)$ \\
\hline $\begin{array}{l}\text { Haemophilus } \\
\text { influenza }\end{array}$ & $2(14)$ & & $1(7)$ & \\
\hline $\begin{array}{l}\text { Pseudomonas } \\
\text { aureoginosa }\end{array}$ & & $1(7)$ & & \\
\hline
\end{tabular}




\begin{tabular}{|c|c|c|c|c|}
\hline Bacteria n, (\%) & $\begin{array}{l}\text { Smoking parents } \\
\mathrm{n}=14 \text { Infection }^{\mathrm{a}} \\
\mathrm{n}=10 \text { Colonization }^{\mathrm{b}} \\
\mathrm{n}=1\end{array}$ & $\begin{array}{l}\text { Smoking parents } \\
\mathrm{n}=14 \text { Infection }^{\mathrm{a}} \\
\mathrm{n}=10 \text { Colonization }^{\mathrm{b}} \\
\mathrm{n}=1\end{array}$ & $\begin{array}{l}\text { Non-smoking } \\
\text { parents } \mathrm{n}=14 \\
\text { Infection } \mathrm{n}=3 \\
\text { Colonization } \mathrm{n}=6\end{array}$ & $\begin{array}{l}\text { Non-smoking } \\
\text { parents } \mathrm{n}=14 \\
\text { Infection } \mathrm{n}=3 \\
\text { Colonization } \mathrm{n}=6\end{array}$ \\
\hline $\begin{array}{l}\text { Serratia } \\
\text { marcescens }\end{array}$ & & & & $1(7)$ \\
\hline $\begin{array}{l}\text { Steptococcus } \\
\text { pneumoniae }\end{array}$ & $1(7)$ & & & $1(7)$ \\
\hline Escherichia coli & & & & $1(7)$ \\
\hline $\begin{array}{l}\text { Stenotrophomonas } \\
\text { maltophilia }\end{array}$ & & & & $1(7)$ \\
\hline $\begin{array}{l}\text { H.influenzae + } \\
\text { M.catharralis }\end{array}$ & $1(7)$ & & & \\
\hline $\begin{array}{l}\text { K.pneumoniae } \\
+ \text { M.catharralis }\end{array}$ & $1(7)$ & & & \\
\hline $\begin{array}{l}\text { S.marcescens + } \\
\text { P.aureoginosa }\end{array}$ & $1(7)$ & & & $1(7)$ \\
\hline $\begin{array}{l}\text { P.aureoginosa }+ \\
\text { K.pneumoniae }\end{array}$ & $1(7)$ & & & \\
\hline $\begin{array}{l}\text { S aureus+ } \\
\text { M.catharralis }\end{array}$ & & & $1(7)$ & \\
\hline $\begin{array}{l}\text { S.pneumoniae + } \\
\text { P.aureoginosa }+ \\
\text { S.marcescens }\end{array}$ & & & $1(7)$ & \\
\hline
\end{tabular}

$\mathrm{CFU} / \mathrm{mL}=$ colony forming units per $\mathrm{mL}^{\mathrm{a}}$ Infection: $>100.000 \mathrm{CFU} / \mathrm{mL}^{\mathrm{b}}$ Colonization [?]100.000 $\mathrm{CFU} / \mathrm{mL}$

A

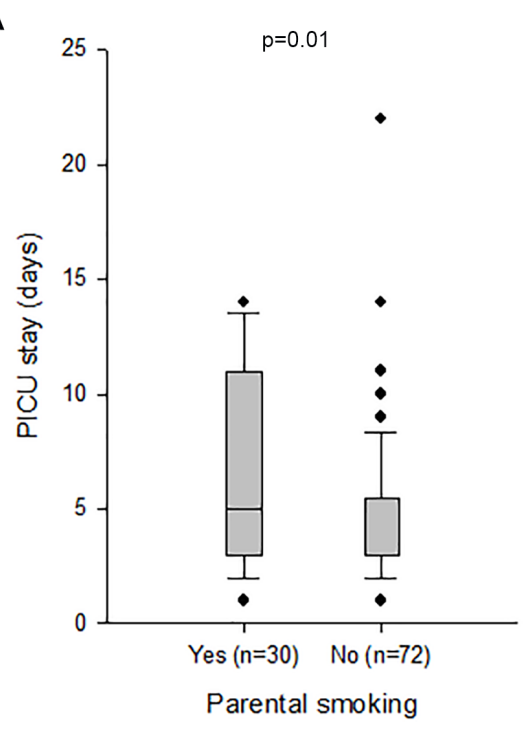

B

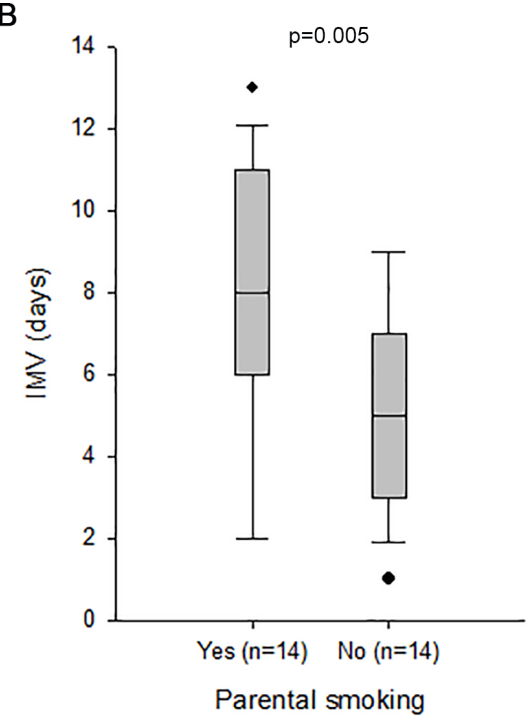


A Smoking $\begin{gathered}\text { Non-smoking } \\ \text { parents }\end{gathered}$

$(n=30) \quad(n=72)$

CXR 21

RSV 26

IMV

14

36
55
14

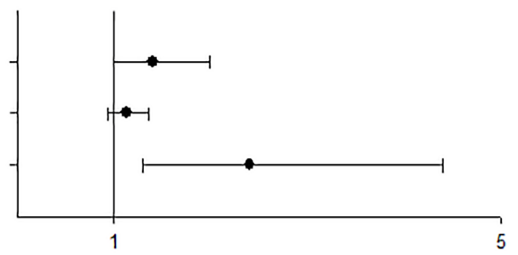

Relative risk

B

$$
\begin{array}{cc}
\text { Smoking } & \text { Non-smoking } \\
\text { parents } & \text { parents } \\
(n=14) & (n=14)
\end{array}
$$

PBI

10
3

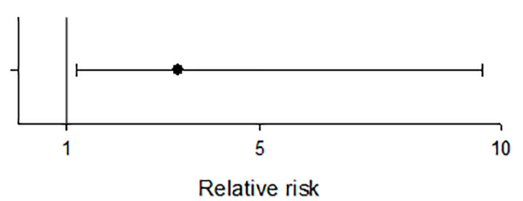

Relative risk (Cl 95\%)

$1.4(1-2)$

$1.1(0.9-1.4)$

$2.4(1.3-4.4)$

Relative risk

(Cl 95\%)

$3.3(1.2-9.6)$ 